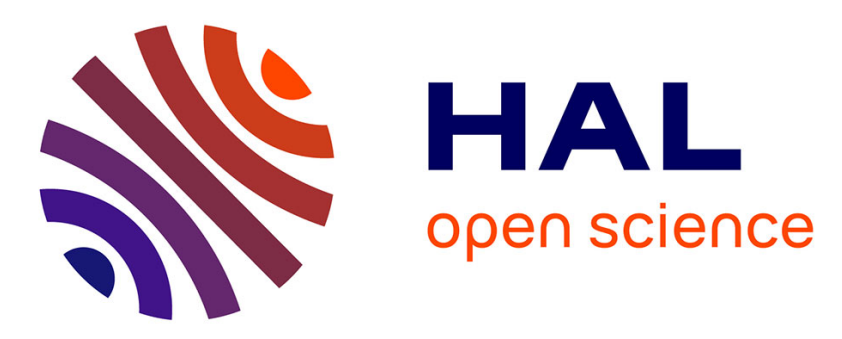

\title{
Comparative Study of Immune Regulatory Properties of Stem Cells Derived from Different Tissues.
}

\author{
Mariano Di Trapani, Giulio Bassi, Mario Ricciardi, Emanuela Fontana, \\ Francesco Bifari, Luciano Pacelli, Luca Giacomello, Michela Pozzobon, \\ Francois Féron, Paolo de Coppi, et al.
}

\section{To cite this version:}

Mariano Di Trapani, Giulio Bassi, Mario Ricciardi, Emanuela Fontana, Francesco Bifari, et al.. Comparative Study of Immune Regulatory Properties of Stem Cells Derived from Different Tissues.. Stem Cells and Development, 2013, 22 (22), pp.2990-3002. 10.1089/scd.2013.0204 . inserm-00868952

\section{HAL Id: inserm-00868952 https://www.hal.inserm.fr/inserm-00868952}

Submitted on 2 Oct 2013

HAL is a multi-disciplinary open access archive for the deposit and dissemination of scientific research documents, whether they are published or not. The documents may come from teaching and research institutions in France or abroad, or from public or private research centers.
L'archive ouverte pluridisciplinaire HAL, est destinée au dépôt et à la diffusion de documents scientifiques de niveau recherche, publiés ou non, émanant des établissements d'enseignement et de recherche français ou étrangers, des laboratoires publics ou privés. 


\title{
Comparative Study of Immune Regulatory Properties of Stem Cells Derived from Different Tissues
}

\author{
Mariano Di Trapani, ${ }^{1, *}$ Giulio Bassi, ${ }^{1, *}$ Mario Ricciardi, ${ }^{1}$ Emanuela Fontana, ${ }^{1,2}$ Francesco Bifari, ${ }^{1}$ \\ Luciano Pacelli, ${ }^{1}$ Luca Giacomello, ${ }^{2}$ Michela Pozzobon, ${ }^{3}$ Francois Féron, ${ }^{4,5}$ Paolo De Coppi, ${ }^{3,6}$ \\ Piero Anversa, ${ }^{7}$ Guido Fumagalli, ${ }^{8}$ Ilaria Decimo, ${ }^{8}$ Cedric Menard, ${ }^{9,10}$ \\ Karin Tarte, ${ }^{9,10}$ and Mauro Krampera ${ }^{1}$
}

\begin{abstract}
Allogeneic stem cell (SC)-based therapy is a promising tool for the treatment of a range of human degenerative and inflammatory diseases. Many reports highlighted the immune modulatory properties of some SC types, such as mesenchymal stromal cells (MSCs), but a comparative study with SCs of different origin, to assess whether immune regulation is a general SC property, is still lacking. To this aim, we applied highly standardized methods employed for MSC characterization to compare the immunological properties of bone marrow-MSCs, olfactory ectomesenchymal SCs, leptomeningeal SCs, and three different c-Kit-positive SC types, that is, amniotic fluid SCs, cardiac SCs, and lung SCs. We found that all the analyzed human SCs share a common pattern of immunological features, in terms of expression of activation markers ICAM-1, VCAM-1, HLA-ABC, and HLA-DR, modulatory activity toward purified T, B, and NK cells, lower immunogenicity of inflammatoryprimed SCs as compared to resting SCs, and indoleamine-2,3-dioxygenase-activation as molecular inhibitory pathways, with some SC type-related peculiarities. Moreover, the SC types analyzed exert an anti-apoptotic effect toward not-activated immune effector cells (IECs). In addition, we found that the inhibitory behavior is not a constitutive property of SCs, but is acquired as a consequence of IEC activation, as previously described for MSCs. Thus, immune regulation is a general property of SCs and the characterization of this phenomenon may be useful for a proper therapeutic use of SCs.
\end{abstract}

\section{Introduction}

A DULT STEM CELLS (SCs) ARE A promising form of treatment for human autoimmune and inflammatory diseases [1-8]. However, it is still unclear whether allogenic adult SCs are rejected by the host immune system due to histoincompatibility [9] or resident SCs per se interfere with the physiological function of the host immune system. Several SC subtypes, including neural SCs [10] and mesenchymal stromal cells (MSCs) [11-14], possess regenerative potential and may interact with immune effector cells (IECs), profoundly influencing their function in vitro and in vivo. The immune system plays a critical role in the pathogenesis and progression of a number of degenerative diseases, raising the possibility that SCs may be effective in repairing the damaged organ by promoting cell formation and modulating the associated immune response [6,14-20]. Based on this premise, the immunogenicity and immune modulatory properties of SCs have to be carefully characterized to decipher their potential clinical import. MSCs from the bone marrow (BM) and adipose tissue (AT) have been well defined [21-27] and similar immune regulatory functions have been identified in

\footnotetext{
${ }^{1}$ Section of Hematology, Stem Cell Research Laboratory, Department of Medicine, University of Verona, Verona, Italy.

${ }^{2}$ Laboratory of Translation Surgery, Department of Surgery, Pediatric Surgery Unit, University of Verona, Verona, Italy.

${ }^{3}$ Laboratory of Stem Cells and Regenerative Therapy, Istituto Ricerca Pediatrica Fondazione Città della Speranza di Padova, University of Padua, Padua, Italy.

${ }^{4}$ Aix Marseille Université, CNRS, NICN, UMR 7259, 13015, Marseille, France.

${ }^{5}$ Centre d'Investigations Cliniques en Biothérapie CIC-B 510, AP-HM, Institut Paoli Calmettes, Inserm, Marseille, France.

${ }^{6}$ Department of Surgery, Great Ormond Street, Hospital for Children, London, United Kingdom.

${ }^{7}$ Division of Cardiovascular Medicine, Departments of Anesthesia and Medicine, Brigham and Women's Hospital, Harvard Medical School, Boston, Massachusetts.

${ }^{8}$ Section of Pharmacology, Department of Public Health and Community Medicine, University of Verona, Verona, Italy.

${ }^{9}$ SITI Laboratory, Etablissement Français du Sang Bretagne, CHU Rennes, France.

${ }^{10}$ INSERM U917, Université Rennes 1, Rennes, France.

*These authors contributed equally to this work.
} 
MSC-like SCs collected from Wharton's jelly, amniotic fluid, and placenta [28-30].

The immunosuppression induced by MSCs is not a direct cellular effect but is mediated by a variety of inflammatory cytokines released by the immune cells recruited to the inflammatory microenvironment [31]; they comprise interferon (IFN)- $\gamma$, tumor necrosis factor (TNF)- $\alpha$, and interleukin (IL)$1-\alpha$ and $-\beta$. In response to these stimuli, MSCs migrate to the site of injury, and become immune modulatory by affecting inflammation and tissue repair in a positive manner. The paracrine mechanisms underlying the impact of MSCs on the local immune adaptation include a broad panel of molecular pathways, such as IFN- $\gamma$, IL- $1 \beta$, transforming growth factor$\beta$, indoleamine-2,3-dioxygenase (IDO), IL-6, IL-10, prostaglandin-E2 (PGE2), hepatocyte growth factor, TNF- $\alpha$, nitric oxide (NO), heme oxygenase-1 (HO-1), HLA-G5 [21,22,3143], and others, some of which are still unknown.

Despite this extensive knowledge acquired on MSCs, several types of adult and nonadult tissue-specific SCs have been characterized, but whether or not these new SC categories exert an immune modulatory function comparable, superior, or inferior to that of MSCs is an important unanswered question. To test this hypothesis, we studied (1) BM-MSCs [25]; (2) olfactory ectomesenchymal SCs (OEMSCs), which are distributed in the olfactory lamina propria and induce neurogenesis, and restore the hippocampal neuronal network [44-46]; (3) non-MSC leptomeningeal SCs (LeSCs), described by us first in rats as nestin-positive cells capable of differentiating into neuronal, astrocyte, and oligodendrocyte precursors $[47,48]$ and, more recently, in mice and humans (personal observation); and (4) human c-Kitpositive SCs isolated from the amniotic fluid (AFSCs) [49], from the adult heart (cardiac SCs: CSCs) [50-52]; and adult lung SCs (LSCs) [53]. AFSCs are multipotent, nonteratogenic cells with characteristics intermediate between embryonic and adult SCs [49]. CSCs are multipotent cells capable of differentiating into cardiomyocytes and coronary vessels [50-52], while LSCs form lung structures of both endodermal and mesodermal origin [53]. The standardized approach previously introduced to characterize MSCs [25] was applied to all SCs to define their immunological profile.

\section{Materials and Methods \\ Isolation and culture of human SCs}

BM-MSCs (five samples) were isolated from BM aspirates of healthy donors (informed consent, approved by Ethical Committee of Azienda Ospedaliera Universitaria Integrata Verona; N. 1828, May 12, 2010- "Institution of cell and tissue collection for biomedical research in Onco-Hematology"). BM aspirates were cultured in $225-\mathrm{cm}^{2}$ flasks at $5 \times 10^{5}$ nucleated cells $/ \mathrm{cm}^{2}$ concentration in alpha-minimal essential medium (MEM), 10\% heat-inactivated fetal bovine serum (FBS), $100 \mathrm{U} / \mathrm{mL}$ penicillin, and $100 \mu \mathrm{g} / \mathrm{mL}$ streptomycin (all from Gibco). After $72 \mathrm{~h}$, nonadherent cells were removed and the medium was replaced twice a week. Full characterization of BM-MSCs has been already described by our group elsewhere $[22,26,28]$.

OE-MSCs (five samples) were obtained under a protocol approved by the local ethical committee (Comité de Protection des Personnes) of Marseille. Informed consent was given by each individual participating in the study, in accordance with the Helsinki convention (1964) and French law relating to biomedical research. OE-MSCs were purified as previously described [44]. Briefly, biopsies from the root of the medial aspect of middle turbinate or the septum in dorsomedial area were washed with Dulbecco modified Eagle medium (DMEM)/HAM F12 and digested for $1 \mathrm{~h}$ with dispase II solution (Boehringer). Then, the olfactory epithelium was removed from underlying lamina propria, which was cut into small pieces with 25 -gauge needle. Tissue fragments were incubated with collagenase $1 \mathrm{~A}$ to complete the tissue dissociation and, after centrifugation, the cell pellet was resuspended in $\alpha$-MEM culture medium supplemented with $10 \%$ heat-inactivated adult bovine serum, $100 \mathrm{U} / \mathrm{mL}$ penicillin, and $100 \mu \mathrm{g} / \mathrm{mL}$ streptomycin (all from Gibco). Full characterization of OE-MSCs has been already described by our group elsewhere [44].

LeSCs (five samples) were obtained as previously described [47] from human brain/spinal cord samples including leptomeninges collected during neurosurgical procedures (informed consent, approved by Ethical Committee of Azienda Ospedaliera Universitaria Integrata Verona; N. 1974, June 1, 201i-“"Institution of meningeal cell and tissue collection for biomedical research in regenerative medicine for neurodegenerative and neurovascular diseases, and spinal cord injury"). Leptomeninges were detached from neural parenchyma, dissociated, and washed with $\alpha$-MEM; adherent cells were cultured in $\alpha$-MEM, $10 \%$ heat-inactivated adult bovine serum, $100 \mathrm{U} / \mathrm{mL}$ penicillin, and $100 \mu \mathrm{g} / \mathrm{mL}$ streptomycin (all from Gibco). Full characterization of LeSCs has been already described by our group elsewhere $[47,48]$ and are part of another specific article.

AFSCs (six samples) were collected from confluent cultures of adherent cells derived from human amniocentesis carried out for diagnostic purposes (cytogenetic analysis), after mother's informed consent; cells were harvested and immediately subjected to immunoselection [49]. Sorted c-Kit positive AFSCs were grown in $\alpha$-MEM medium (Gibco) containing heat-inactivated adult bovine serum, $100 \mathrm{U} / \mathrm{mL}$ penicillin, and $100 \mu \mathrm{g} / \mathrm{mL}$ streptomycin (all from Gibco), supplemented with 18\% Chang B and 2\% Chang C (Irvine Scientific). Full characterization of AFSCs has been already described by our group elsewhere [49].

CSCs and LSCs (three samples each) were obtained from enzymatic dissociation of myocardial and lung tissues, respectively, and cultured as adherent cells as previously described [50,53].

All SC types were detached (0.05\% Tripsin-EDTA; Gibco) and harvested when $80 \%$ confluent, and then either reseeded at $10^{3} / \mathrm{cm}^{2}$ concentration or frozen until use. All experiments were performed between passages 2 and 6 . Full characterization of CSCs and LSCs has been already described by our group elsewhere [50,53].

Each SC type was characterized in terms of phenotype and differentiation potential $[22,44,50,53,54]$ following International Society for Cellular Therapy (ISCT)-minimal criteria [55].

\section{Immunofluorescence}

SCs were harvested at $80 \%$ confluence and $2 \times 10^{4}$ cells were seeded on glass dishes pretreated with gelatin or polyD-lysine (Sigma Aldrich) in 24-well plates. After 24h, cultures were fixed with $4 \%$ paraformaldehyde and stained 
with appropriate antibody: mouse-anti-human CD73-PE (BD Biosciences) for BM-MSCs, rabbit-anti-human nestin (Abcys) for OE-MSCs, mouse-anti-human nestin (BD Biosciences) for LeSCs, rabbit-anti-human c-Kit (DAKO) for AFSCs, CSCs, and LSC; as secondary antibodies, goat-anti-rabbitAlexaFluor-549, goat-anti-mouse-AlexaFluor-488, and donkeyanti-rabbit-FITC (all from Invitrogen) were used, respectively. Hoechst-33342 or TOPRO-3 (Invitrogen) were added to reveal nuclei. Images were obtained by fluorescence or confocal microscopy at $20 \times$ or $40 \times$ magnification.

\section{Immunophenotyping}

SCs at $80 \%$ confluence were stimulated or not for $40 \mathrm{~h}$ with $10 \mathrm{ng} / \mathrm{mL}$ IFN- $\gamma$ and $15 \mathrm{ng} / \mathrm{mL}$ TNF- $\alpha$ (R\&D Systems). The lack of cytotoxic effects of this inflammatory cytokines was previously confirmed [56]. Rested and primed SCs were stained with the following monoclonal antibodies against

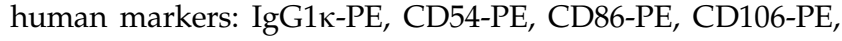
CD200-PE, and HLA-ABC-PE all from BD Biosciences;

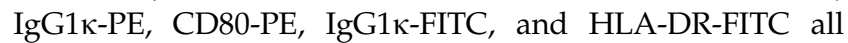
from Beckman Coulter; IgG1к-PE, CD112-PE, CD155-PE, IgG2b-PE, and CD274-PE all from Biolegend; IgG2a-PE, unconjugated IgG2a, MICA/B-PE, ULBP-1-PE, ULBP-2-PE, and unconjugated ULBP-3 all from R\&D Systems, and goatanti-mouse-PE from DAKO.

For staining, $10^{5}$ SCs were incubated with the selected monoclonal antibody or appropriate isotype control in PBS for $15 \mathrm{~min}$ at room temperature. For ULBP-3 expression, PEconjugated goat anti-mouse $\operatorname{IgG~} \mathrm{F}\left(\mathrm{ab}^{\prime}\right)_{2}$ was added, after staining the cells with specific primary unconjugated antibody. According to manufacturer's instruction, ULBP-1 expression was validated by intracellular staining using the Cytofix/Cytoperm kit (BD Biosciences). Data were analyzed by FACSCalibur and FACSCanto (BD Biosciences) and expressed as the ratio of geometric mean fluorescence intensity (rMFI) obtained for each marker and its isotype-matched negative control.

\section{Evaluation of immunomodulation and anti-apoptotic effects}

IECs (CD3 $3^{\text {pos }} \mathrm{T}$ cells, $\mathrm{CD} 19^{\text {pos }} \mathrm{B}$ cells, and CD56 ${ }^{\text {pos }} \mathrm{NK}$ cells) were purified from peripheral blood using appropriate negative selection kits (Miltenyi Biotec) with at least 95\% cell purity, as evaluated by flow cytometry. In each well, rested and primed SCs were seeded with IECs at either $2 \times 10^{4}$ cell concentration (high ratio, corresponding to a confluent monolayer), or $2 \times 10^{3}$ cell concentration (low ratio). After SC adhesion, $2 \times 10^{5} \mathrm{~T}$ cells, $2 \times 10^{4} \mathrm{~B}$ cells, or $2 \times 10^{4} \mathrm{NK}$ cells previously stained with $5 \mu \mathrm{M}$ carboxyfluorescein succinimidyl ester (Life Technologies) were added. T cells were activated with $0.5 \mu \mathrm{g} / \mathrm{mL}$ cross-linking antiCD3 and anti-CD28 antibodies (Sanquin) for 6 days in Roswell Park Memorial Istitute (RPMI) supplemented with $10 \%$ human $\mathrm{AB}$ serum. $\mathrm{B}$ cells were activated with $2 \mu \mathrm{g} / \mathrm{mL} \mathrm{F}\left(\mathrm{ab}^{\prime}\right)_{2}$ anti-human IgM/IgA/IgG (Jackson Immunoresearch), $20 \mathrm{IU} / \mathrm{mL}$ rhIL-2 (Proleukin; Novartis), 50 ng/mL polyhistidine-tagged CD40 ligand, $5 \mu \mathrm{g} / \mathrm{mL}$ anti-polyhistidine antibody (R\&D Systems), and $2.5 \mu \mathrm{g} / \mathrm{mL} \mathrm{CpG} \mathrm{B} \mathrm{(Invivogen)} \mathrm{for} 4$ days in RPMI supplemented with 10\% FBS (Invitrogen Life Technologies). NK cells were activated by $100 \mathrm{IU} / \mathrm{mL}$ rhIL-2 for 6 days in Iscove modified Dulbecco medium (IMDM) supplemented with $10 \%$ human $\mathrm{AB}$ serum. At the end of coculture, cells were detached by trypsin and stained with PerCP mouse anti-human CD45 monoclonal antibody BD Biosciences and TOPRO-3 Iodide (Invitrogen Life Technologies); the proliferation was assessed on viable $\mathrm{TOPRO}-3^{\text {neg }} \mathrm{CD} 45^{\text {pos }}$ cells by FACS analysis as the percentage of cells undergoing at least one cell division. The proliferation rate was obtained according to the following formula: (percentage of $\mathrm{CD} 45^{\mathrm{pos}}$ cell proliferation with $\mathrm{SCs}$ )/(percentage of $\mathrm{CD} 45^{\mathrm{pos}}$ cell proliferation without $\mathrm{SCs})^{*} 100$.

To evaluate the molecular pathways involved in immune regulation, the following specific inhibitors were added to SC/T cell cocultures: $1 \mathrm{mM}$ L-N-monomethylarginin (LNMMA)—inhibitor of inducible NO synthase (iNOS); $5 \mu \mathrm{M}$ NS-398 (Cayman Chemicals)-inhibitor of cyclooxygenase-2 (COX-2) that is necessary for PGE2 synthesis; $1 \mathrm{mM} \mathrm{L-1-}$ methyltryptophan (L-1MT)-IDO inhibitor (Sigma-Aldrich); $2 \mu \mathrm{M}$ tin-protoporphyrin (SnPP)-inhibitor of HO-1 (Frontier Scientific); and $10 \mu \mathrm{g} / \mathrm{mL}$ purified anti-human IFN- $\gamma$ NA/LE mouse IgG1 (BD Biosciences).

To determine the IEC survival, primed and rested SCs were seeded with IECs at the same ratios used for the immunosuppression assays. Cells were analyzed after either 4 days (B and NK cells) or 6 days of coculture (T cells). Cells were then harvested and stained with Allophycocyanin (APC) mouse anti-human CD45 BD Biosciences and lymphocyte survival was assessed following manufacturer's instructions (PE active caspase-3 apoptosis kit; BD Biosciences). Briefly, fixed and permeabilized cells were stained with PE-anti-caspase-3 antibodies and cell survival was assessed as percentage of activecaspase- $-3^{\text {neg }} C D 45^{\text {pos }}$ viable cells by FACS analysis.

\section{Immunogenicity assay}

Resting and primed SC immunogenicity was evaluated in a nonradioactive cytotoxicity assay using rh-IL-2 activatedNK cells as effector cells, following manufacturer's instructions (Delfia Cytotoxicity kit; Perkin Elmer). Briefly, SCs were loaded with bis-acetoxymethyl terpyridine dicarboxylate (BATDA) fluorescent dye and then incubated for $3 \mathrm{~h}$ with various ratios of allogeneic NK cells preactivated for $48 \mathrm{~h}$ with $100 \mathrm{IU} / \mathrm{mL}$ rhIL-2. Cytotoxicity was quantified by assessing fluorescence release in coculture supernatants by a time-resolved fluorimeter (Victor ${ }^{\mathrm{TM}} \mathrm{X} 4$, Perkin Elmer).

\section{Bioinformatics}

Hierarchical cluster analysis of protein expression was used to group SCs with similar expression pattern. Molecular markers with differential expression pattern among various SC types were selected from the rMFI derived from immunophenotyping. The expression data were logarithm transformed and grouped using hierarchical clustering algorithm in Gene Cluster 3.0 program [57]. Heat-map was performed using Java Treeview program [58].

\section{Statistical analysis}

Data were expressed as mean \pm standard deviation, except for immunophenotype data that were expressed as mean \pm standard error of the mean. Statistical analysis was performed by Prism software (GraphPad) using the Wilcoxon test to compare the effect of priming on the same 
SCs, while one-way ANOVA test was used to assess the differences among SCs types. $P<0.05$ was considered statistically significant.

\section{Results}

\section{IFN- $\gamma$ and TNF- $\alpha$ strongly regulate SC immunophenotype}

Previous reports have highlighted the differences among the SC types employed in this study in terms of marker expression, morphology (Fig. 1), differentiation potential, in vivo engraftment, and regenerative capabilities. The immunophenotype of resting and IFN- $\gamma$ - and TNF- $\alpha$-primed BM-MSCs, OE-MSCs, LeSCs, AFSCs, CSCs, and LSCs was studied in parallel (Table 1 and Supplementary Fig. S1; Supplementary Data are available online at www.liebertpub

.com/scd), also by using a hierarchical cluster analysis (Fig. 2). These SC types expressed HLA-ABC molecules at different levels. At baseline, HLA-ABC molecules were more abundant in OE-MSCs and LeSCs than in BM-MSCs, AFSCs, CSCs, and LSCs; however, following inflammatory priming, HLA-ABC molecules increased in all SC categories, and significant changes occurred in LeSCs (2.6-fold), AFSCs (2.2-fold), CSCs (2.0fold), and LSCs (3.2-fold). In control conditions, HLA-DR was scarcely or partially expressed by BM-MSCs, but after inflammatory priming, it dramatically increased in BM-MSCs, OEMSCs, and LSCs; low levels of HLA-DR were detected in primed AFSCs, LeSCs, and CSCs. The costimulatory molecules CD80 and CD86 were undetectable in all SC types with the exception of resting CSCs; however, CD86 was no longer detectable in CSCs after inflammatory priming. CD40 was weakly expressed in resting OE-MSCs and AFSCs, but a significant increase in CD40 was observed after inflammatory priming in BM-MSCs (3.2-fold), OE-MSCs (2.0-fold), and LeSCs (3.8-fold). Primed AFSCs did not upregulate CD40, and CSCs and LSCs never expressed this marker.

Two adhesion molecules CD54 (ICAM-1) and CD106 (VCAM-1), which are involved in cell migration and interaction between MSCs and inflammatory cells [59-61], were tested. CD54 was highly expressed in OE-MSCs, and low levels of this molecule were detected in the other SCs. CD54 was markedly upregulated in all primed SC types (BMMSCs, 174.6-fold, OE-MSCs, 39.6-fold, LeSCs, 112.0-fold, AFSCs, 44.7-fold, CSCs, 47.0-fold, and LSCs, 129.0-fold). CSCs and LSCs did not express CD106 at baseline, and only primed CSCs showed CD106 weakly. Conversely, BMMSCs, OE-MSCs, LeSCs, and AFSCs constitutively expressed CD106, which was significantly upregulated after priming (BM-MSCs, 4.3-fold, OE-MSCs, 2.0-fold, LeSCs, 12.0-fold, and AFSCs, 14.0-fold).

CD200 and CD274 (PD-L1) modulate the immune response via a cell-to-cell contact-dependent mechanism [6264]. CD200 was highly expressed in CSCs, modestly present in BM-MSCs and OE-MSCs, and absent in AFSCs, LeSCs, and LSCs. After inflammatory priming, a 2.7-fold downregulation of CD200 occurred in CSCs while no changes were observed in the other SCs. At baseline, CD274 was constitutively expressed in all SCs but mostly in OE-MSCs and AFSCs. Inflammatory priming resulted in a proportional upregulation of CD274 in the various SC categories.

The NK cell-activating ligands were evaluated $[27,65]$. CD112 (nectin-2) and CD155 Poliovirus receptor (PVR), which stimulate the DNAX Accessory Molecule-1 (DNAM-1) receptor, were expressed at high levels in all SCs at baseline. Inflammatory priming increased by $\sim 2$-fold the expression
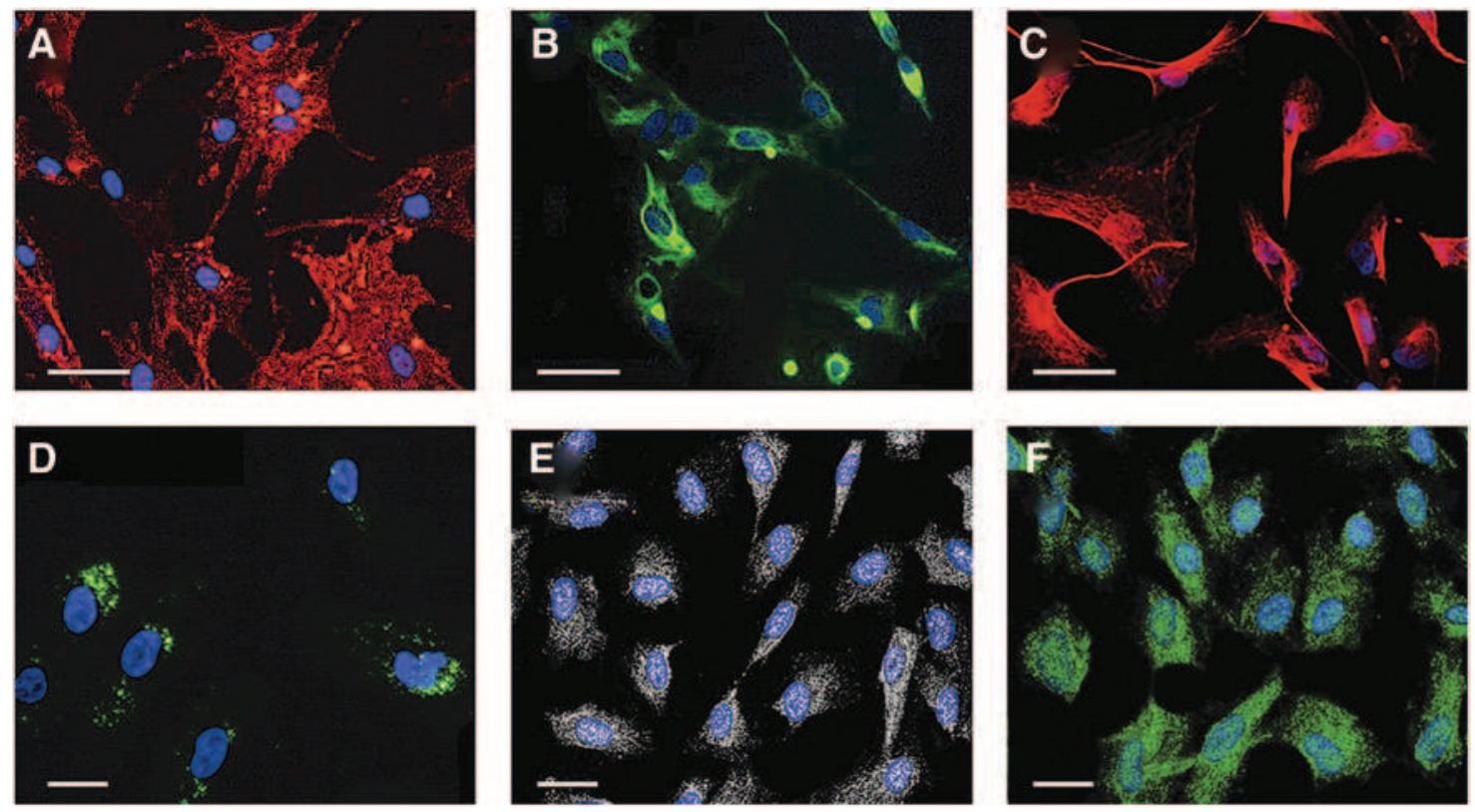

FIG. 1. Representative immunofluorescence staining of various human stem cell (SC) types. (A) Bone marrow (BM)mesenchymal stromal cells (MSCs) were stained with anti-CD73-PE (red) and TOPRO-3 (blue); (B) olfactory ectomesenchymal SCs (OE-MSCs) were stained with anti-Nestin (green) and Hoechst-33342 (blue); (C) leptomeningeal SCs (LeSCs) were stained with anti-Nestin (red) and TOPRO-3 (blue); (D) amniotic fluid SCs (AFSCs) were stained with anti-c-Kit (green) and TOPRO-3 (blue); (E) cardiac SC (CSCs) were stained with anti-c-Kit (white) and TOPRO-3; (F) lung SCs (LSCs) were stained with anti-cKit (green) and TOPRO-3 (blue). Scale bars: $50 \mu \mathrm{m}$ (A-C); $20 \mu \mathrm{m}$ (D-F). 
Table 1. Expression of Different Markers on Various Human SCs in Resting and Primed Conditions

\begin{tabular}{|c|c|c|c|c|c|c|}
\hline Marker/SCs & $B M-M S C$ & $O E-M S C$ & LeSC & AFS & CSC & $L S C$ \\
\hline \multicolumn{7}{|c|}{ Immunological } \\
\hline \multirow[t]{2}{*}{ HLA-ABC } & $16.97 \pm 2.48$ & $29.42 \pm 5.46$ & $22.83 \pm 4.32$ & $11.29 \pm 2.98$ & $5.15 \pm 0.17$ & $2.74 \pm 0.1$ \\
\hline & $27.37 \pm 6.1$ & $35.4 \pm 5.47$ & $59.34 \pm 10.2^{* *}$ & $25.3 \pm 3.82^{* * *}$ & $10.37 \pm 0.66^{*}$ & $8.7 \pm 0.6^{*}$ \\
\hline \multirow[t]{2}{*}{ HLA-DR } & $1.42 \pm 0.21$ & $1 \pm 0$ & $1.04 \pm 0.04$ & $1.02 \pm 0.02$ & $1 \pm 0$ & $1.1 \pm 0.04$ \\
\hline & $21.91 \pm 3.61^{* *}$ & $15.04 \pm 2.56^{*}$ & $1.58 \pm 0.17$ & $2.66 \pm 0.91$ & $3.53 \pm 0.1^{* *}$ & $12.06 \pm 0.3^{* *}$ \\
\hline \multirow[t]{2}{*}{ CD40 } & $1.29 \pm 0.14$ & $1.93 \pm 0.17$ & $1.19 \pm 0.12$ & $2.1 \pm 0.26$ & $1 \pm 0$ & $1 \pm 0$ \\
\hline & $4.14 \pm 0.74^{*}$ & $3.8 \pm 0.27^{* *}$ & $4.55 \pm 0.66^{*}$ & $2.4 \pm 0.07$ & $1 \pm 0$ & $1 \pm 0$ \\
\hline \multirow[t]{2}{*}{ CD80 } & $1 \pm 0$ & $1 \pm 0$ & $1 \pm 0$ & $1 \pm 0$ & $1 \pm 0$ & $1 \pm 0$ \\
\hline & $1.36 \pm 0.04$ & $1 \pm 0$ & $1 \pm 0$ & $1 \pm 0$ & $1 \pm 0$ & $1.07 \pm 0.06$ \\
\hline \multirow[t]{2}{*}{ CD86 } & $1.24 \pm 0.07$ & $1.09 \pm 0.09$ & $1.11 \pm 0.05$ & $1.26 \pm 0.16$ & $2.2 \pm 0.15$ & $1 \pm 0$ \\
\hline & $1.02 \pm 0.02$ & $1.34 \pm 0.31$ & $1.18 \pm 0.18$ & $1.17 \pm 0.09$ & $1.06 \pm 0.05^{*}$ & $1 \pm 0$ \\
\hline \multicolumn{7}{|c|}{ Adhesion proteins } \\
\hline \multirow[t]{2}{*}{ CD54 } & $6.83 \pm 2.68$ & $35.28 \pm 6.51$ & $9.67 \pm 1.2$ & $14.04 \pm 4.78$ & $4.43 \pm 0.9$ & $2.1 \pm 0.14$ \\
\hline & $1193 \pm 98^{* *}$ & $1400 \pm 156^{* * *}$ & $1082 \pm 101^{* *}$ & $626 \pm 60.9^{* * *}$ & $208 \pm 14.54^{* *}$ & $271 \pm 13.5^{* *}$ \\
\hline \multirow[t]{2}{*}{ CD106 } & $5.8 \pm 2.08$ & $6.11 \pm 1.54$ & $2.06 \pm 0.19$ & $1.89 \pm 0.27$ & $1 \pm 0$ & $1 \pm 0$ \\
\hline & $25.3 \pm 10.62$ & $12.47 \pm 4.62$ & $25 \pm 5.12^{*}$ & $26.58 \pm 7.3^{*}$ & $1.57 \pm 0.07^{*}$ & $5.16 \pm 0.4^{*}$ \\
\hline \multicolumn{7}{|c|}{ Immunomodulatorry } \\
\hline \multirow[t]{2}{*}{ CD200 } & $3.47 \pm 1.56$ & $2.82 \pm 0.76$ & $1.06 \pm 0.02$ & $1.17 \pm 0.06$ & $17.24 \pm 6.64$ & $1 \pm 0$ \\
\hline & $3.73 \pm 1.06$ & $1.86 \pm 0.45$ & $1.15 \pm 0.12$ & $1.18 \pm 0.1$ & $6.03 \pm 0.42$ & $1 \pm 0$ \\
\hline \multirow[t]{2}{*}{ PD-L1 } & $5.28 \pm 0.55$ & $15.68 \pm 2.68$ & $2.17 \pm 0.14$ & $23.88 \pm 4.2$ & $3.72 \pm 0.21$ & $4.37 \pm 0.1$ \\
\hline & $76.14 \pm 6.65^{* *}$ & $96.42 \pm 26.51^{*}$ & $60.45 \pm 17.3^{*}$ & $80.2 \pm 12.7^{* *}$ & $12.63 \pm 0.38^{* * *}$ & $8.4 \pm 1.17^{* *}$ \\
\hline \multicolumn{7}{|l|}{ NK ligands } \\
\hline \multirow[t]{2}{*}{ CD112 } & $11.87 \pm 2$ & $30.86 \pm 4.75$ & $12.5 \pm 4.33$ & $23.7 \pm 1.37$ & $7.18 \pm 1.21$ & $4.95 \pm 0.26$ \\
\hline & $26.45 \pm 5.67^{*}$ & $62.38 \pm 8.78^{* *}$ & $27.87 \pm 5.07^{* *}$ & $33.8 \pm 4.2$ & $5.23 \pm 0.02$ & $3.54 \pm 0.16$ \\
\hline \multirow[t]{2}{*}{ CD155 } & $17.9 \pm 3.78$ & $57.86 \pm 12.8$ & $57.82 \pm 20.35$ & $78.48 \pm 17.9$ & $7.9 \pm 1.47$ & $6.23 \pm 0.44$ \\
\hline & $29.48 \pm 7.84$ & $128.5 \pm 31$ & $103.8 \pm 12^{*}$ & $102.7 \pm 13.04$ & $6.88 \pm 0.04$ & $8.2 \pm 0.3$ \\
\hline \multirow[t]{2}{*}{$\mathrm{MICA} / \mathrm{B}$} & $1.7 \pm 0.24$ & $1.19 \pm 0.17$ & $1.07 \pm 0.08$ & $1.75 \pm 0.4$ & $1.57 \pm 0.06$ & $1.15 \pm 0.02$ \\
\hline & $1.16 \pm 0.1$ & $1.06 \pm 0.06$ & $1 \pm 0$ & $1.43 \pm 0.36$ & $1.03 \pm 0.03$ & $1.18 \pm 0.08$ \\
\hline \multirow[t]{2}{*}{ ULBP-1 } & $1.79 \pm 0.21$ & $1.43 \pm 0.08$ & $1.43 \pm 0.04$ & $1.23 \pm 0.02$ & $1.14 \pm 0.06$ & $1 \pm 0$ \\
\hline & $1.67 \pm 0.27$ & $1.58 \pm 0.13$ & $1.47 \pm 0.16$ & $1.46 \pm 0.1$ & $1.31 \pm 0.06$ & $1 \pm 0$ \\
\hline \multirow[t]{2}{*}{ ULBP-2 } & $3.73 \pm 1.8$ & $2.47 \pm 0.28$ & $2.31 \pm 0.45$ & $3.12 \pm 0.55$ & $3.84 \pm 0.02$ & $1.4 \pm 0.01$ \\
\hline & $3.04 \pm 0.66$ & $1.54 \pm 0.23^{*}$ & $2 \pm 0.3$ & $1.88 \pm 0.23^{*}$ & $2.38 \pm 0.08$ & $1.12 \pm 0.06$ \\
\hline \multirow[t]{2}{*}{ ULBP-3 } & $2.3 \pm 1.04$ & $1.3 \pm 0.27$ & $1.16 \pm 0.12$ & $1.64 \pm 0.59$ & $2.2 \pm 0.07$ & $3.24 \pm 0$ \\
\hline & $1.35 \pm 0.2$ & $1.15 \pm 0.1$ & $1.54 \pm 0.46$ & $2.38 \pm 0.68$ & $2.6 \pm 0.11^{*}$ & $1.04 \pm 0.03^{* * *}$ \\
\hline
\end{tabular}

Cells were cultured for $48 \mathrm{~h}$ under normal or inflammatory conditions, stained with different antibodies and analyzed by flow cytometry. Data are presented as mean \pm SEM of relative Mean Fluorescence Intensity (rMFI) of five (BM-MSCs, OE-MSCs, AFSCs, and LeSCs) or three (CSCs, LSCs) different experiments derived from resting (upper) and primed (below) SCs for each marker.

${ }^{*} P<0.05,{ }^{* *} P<0.01,{ }^{* * *} P<0.001$.

SC, stem cell; BM-MSC, bone marrow-mesenchymal stromal cells; OE-MSC, olfactory ectomesenchymal SCs; LeSC, leptomeningeal SCs; AFS, amniotic fluid SCs; CSC, cardiac SCs; LSC, lung SCs.

of CD112 and CD155 in all SCs but CSCs and LSCs. In the latter two cases, priming did not alter the levels of CD112 and CD155. The ligands of the NKG2D receptor, MICA/B and ULBPs, were then examined. ULBP-1, ULBP-2, ULBP-3, and MICA/B were not particularly abundant at resting conditions and after inflammatory priming in all SC populations.

Overall, the immunophenotype observed at resting and inflammatory conditions show many similarities among different SC types; moreover, the clustering analysis highlighted a clear distinction between resting and primed SCs, which suggests a common pattern of protein modulation induced by inflammatory mileu (Fig. 2). These data are in agreement with defective antigen-presenting cell functions (expression of HLA class I and class II molecules without coexpression of costimulatory molecules) and activating capability toward NK cells due to the partial expression of NK cell-activating receptors possibly leading to SC rejection; nevertheless, the latter activity may be counterbalanced fol- lowing inflammatory priming by the upregulation of HLA class I molecules triggering inhibitory NK receptors.

\section{SCs share immunomodulatory properties}

MSCs from several organs exert comparable regulatory effects on cells belonging to the innate and acquired immunity. Thus, we determined whether the variety of SC types included in the current study possessed similar immunological properties. Resting or primed SCs were cocultured with purified T-, NK-, and B cells to evaluate their ability to induce proliferation of unstimulated IECs. All SC types neither activated nor promoted IEC growth (data not shown). Then, the role of SCs in IEC replication was assessed by using different IEC:SC ratios, which ranged from 10:1 (high ratio) to 100:1 (low ratio) for T cells, and from 1:1 (high ratio) to 10:1 (low ratio) for NK and $\mathrm{B}$ cells, according to the standardized approach previously used with BM-MSCs [25]. At resting and primed conditions, none of the SC types 
FIG. 2. Hierarchical cluster analysis of protein expression of various human SCs in resting and primed conditions. Modulation of expression of fifteen proteins in resting and inflammatory-primed conditions. Heat map showed the down(green) or upregulation (red) of protein expression. Different samples were grouped using hierarchical clustering algorithm.

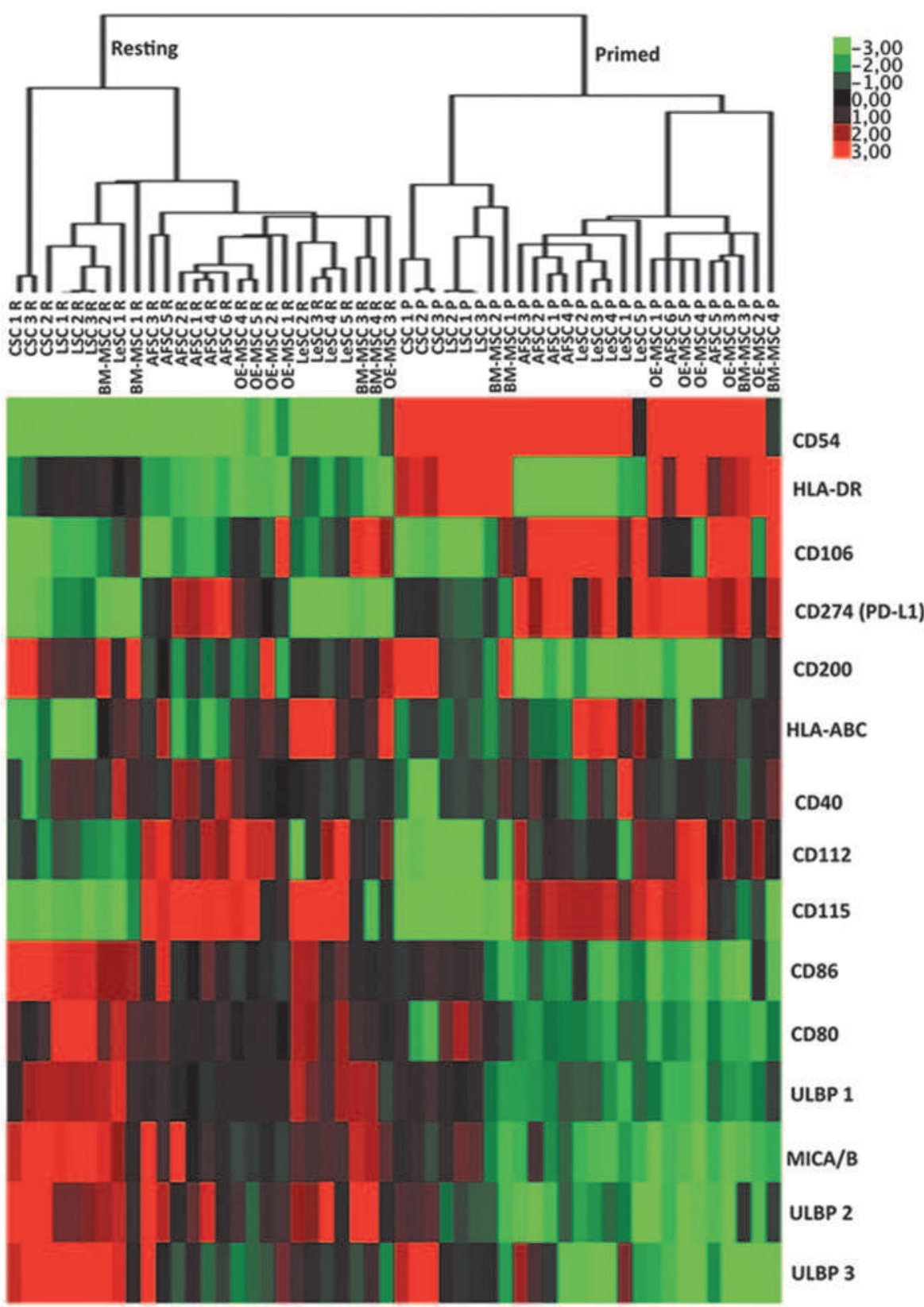

displayed a modulatory function on IECs at low ratios (data not shown). Conversely, at high ratios, all SCs inhibited T cell division at resting conditions, and significantly more following pretreatment with inflammatory cytokines (Fig. 3A). OE-MSCs, LeSCs, CSCs, and LSCs showed a greater immunomodulatory effect than AFSCs and BM-MSCs.

All SCs with the exception of LeSCs displayed inhibitory properties on NK cells in absence of pretreatment with IFN- $\gamma$ and TNF- $\alpha$ (Fig. 3B). Resting and primed OE-MSCs inhibited proliferation of NK cells by more than $90 \%$. Resting LSCs and CSCs had an intermediate effect on NK cell proliferation, and BM-MSCs and AFSCs had the lowest. Primed BM-MSCs had a partial enhanced immunosuppressive activity, a response that was not detected in AFSCs, LSCs, and CSCs. LeSCs had no effect at baseline but, following priming, manifested a strong immunodulatory function comparable to OE-MSCs, and higher than BM-MSCs.
In the absence of inflammatory stimuli, MSCs cannot inhibit B cell growth due to the lack of IFN- $\gamma$ release [22]. Although resting LSCs enhanced B cell proliferation, the other resting SC types failed to demonstrate any immunomodulatory function on B cells (Fig. 3C). However, primed SCs inhibited B cell replication. OE-MSCs and LeSCs showed an effect that was significantly greater than in the other SCs including BM-MSCs. Collectively, distinct SC categories possess common immunomodulatory properties, which at times differ qualitative and quantitatively (Table 2).

\section{Molecular pathway in SC-mediated immunomodulation}

To dissect the mechanisms responsible for the impact of SCs on T cell division, specific inhibitors (L-1MT, LNMMA, NS-398, and snPP) were added to SC-T cell cultures at doses 

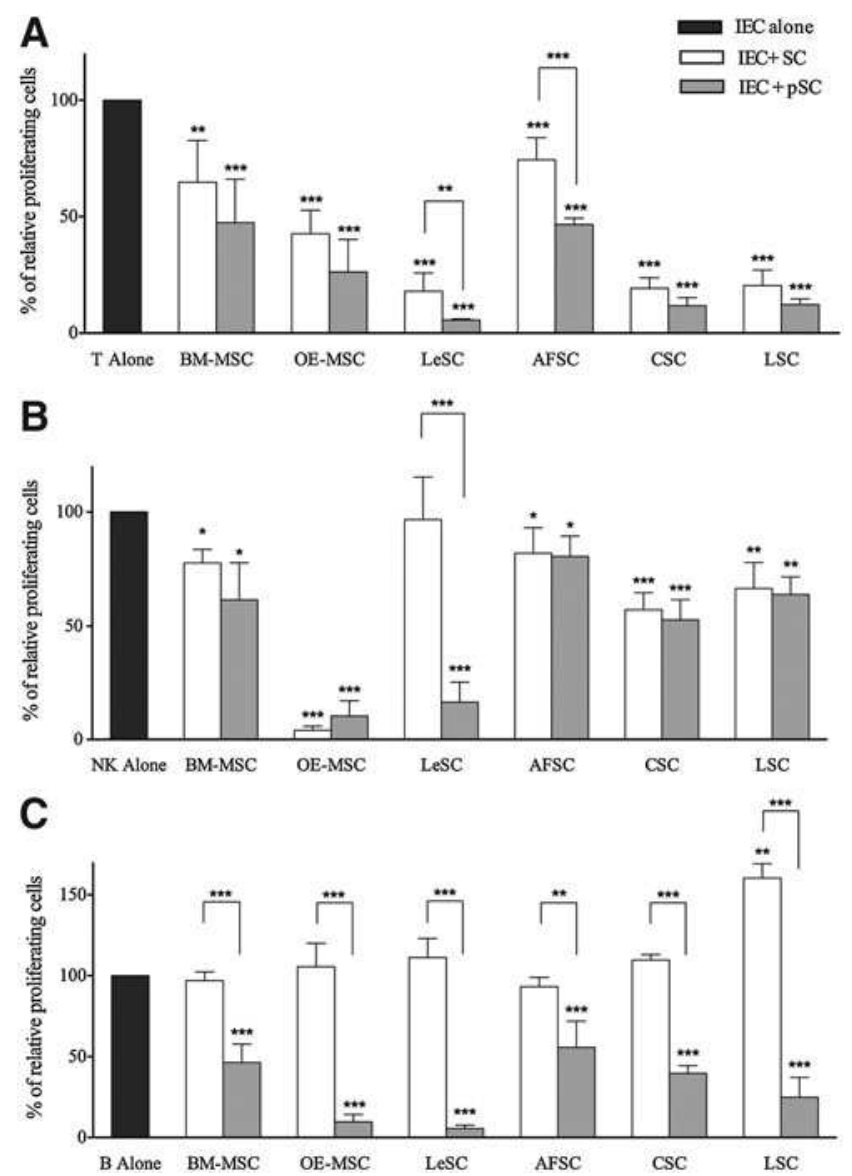

FIG. 3. Human SC inhibitory effect on stimulated immune effector cell (IEC) proliferation. Human IEC (ie, T, NK, and B cells) were stimulated with specific stimuli and cultured alone (dark gray bars) or in the presence of resting (white bars) or primed (light gray bars) allogeneic human SCs. At the end of coculture, lymphocyte proliferation was assessed using carboxyfluorescein succinimidyl ester (CFSE) dilution method, as described in Materials and Methods section. CFSE fluorescence was analyzed after 7 days for $\mathrm{T}$ (at 10:1 $\mathrm{T} / \mathrm{SC}$ ratio) and NK (at 1:1 NK/SC ratio) cells (A and $\mathbf{B}$, respectively), while for $B$ cells $(C)$ the fluorescence was detected after 4 days of coculture (at 1:1 B/SCs ratio). The results are expressed as relative proliferation percentage of IEC, normalized to IEC cultured alone (100\%). Error bars represented mean $\pm S D$ of five independent experiments for BM-MSCs, OE-MSCs, LeSCs, and AFSCs and three independent experiments for CSCs and LSCs. ${ }^{*} P<0.05,{ }^{* *} P<0.01$, $* * * P<0.001$.

that did not alter T cell viability and growth. The neutralizing anti-IFN- $\gamma$ monoclonal antibody was also used to define the role of this cytokine in immune modulation. With the exception of resting OE-MSCs, L-1MT completely rescued T cell proliferation in the presence of resting or primed SCs; this result indicates that IDO is a major determinant of the anti-proliferative effects that SCs have on T cells (Fig. 4). Conversely, inhibitors COX-2 (NS-398), HO-1 (snPP), and IFN- $\gamma$ blocking antibody only partly restored $\mathrm{T}$ cell replication. The iNOS inhibitor LNMMA, however, failed to restore $\mathrm{T}$ cell division in the presence of either resting or primed human SCs (data not shown). NS-398 interfered with PGE2 synthesis attenuating the effects of resting LeSCs and primed BM-MSCs. Interestingly, snPP-mediated HO-1 inhibition modestly reactivated CSC-induced T cell suppression.

Collectively, our observations suggest that the anti-proliferative effects of SC types on T cells is predominantly driven by the activation of IDO and the degradation of tryptophan (Table 2), an essential factor for $\mathrm{T}$ cell division and the generation of kynurenine, a critical immunomodulatory molecule.

\section{Inflammatory priming, SC immunogenicity, and NK-mediated lysis}

Treatment of BM-MSCs with inflammatory cytokines reduces the susceptibility of these cells to NK cell-mediated lysis [27]. This phenomenon is initiated by the expression in BM-MSCs of surface molecules, induced by the inflammatory milieu, which have the ability to activate or inhibit NK receptors [65,66]. These ligands, including CD112, CD155, MICA/B, ULBPs, and HLA class I and II molecules, are present in the SC types studied here (Table 1). To assess whether SCs are sensitive to NK cell-mediated cytotoxicity, BATDA stained-SCs were cocultured with different ratios of IL-2-stimulated NK cells. Cytotoxicity activity was measured by the quantity of BATDA released in the medium that is proportional to NK cell-mediated lysis. NK cells were capable of partially lysing resting SCs, and this effect was directly proportional to the increase of NK/SC ratio (Fig. 5 and Table 2). However, an opposite effect was observed when SCs were pretreated with IFN- $\gamma$ and TNF- $\alpha$; SCs were significantly less vulnerable, suggesting that the differential expression of surface molecules attenuates the susceptibility of SCs to NK-mediated lysis.

\section{SC and lymphocyte survival}

Resting MSCs prevent $\mathrm{T}$ cell apoptosis promoted by the engagement of $\mathrm{T}$ cell receptors [67]. On the basis of these observations, we tested whether different SC types were capable of protecting IEC survival and whether this effect was modulated by inflammatory priming. Unstimulated $\mathrm{T}$, $\mathrm{NK}$, and B cells were cultured alone or in presence of either resting or primed SCs at different ratios. After 4 days (B and NK cells) and 6 days (T cells), cocultured cells were harvested and stained with anti-active-caspase 3 antibody, and analyzed by flow cytometry. Resting and primed SCs significantly reduced IEC apoptosis (Fig. 6). This phenomenon was less apparent in T cells, possibly due to the higher survival of this cell type with respect to B and NK cells. We also found a dose-dependent anti-apoptotic effect of BM-MSCs, OE-MSCs, and LeSCs on B cells.

\section{Discussion}

Cell loss, inflammation, immune system activation, and cell renewal occur following tissue injury. Alterations in this sequence of events result in inadequate organ repair giving rise to pathologic states $[11,19,68,69]$. Inflammatory priming has been viewed as a requirement for MSCs to have immune modulatory properties in vitro and in vivo [4-6,11-14]. The origin of MSCs, the secretion of soluble factors conferring proper SC licensing, and the level of inflammation at the site of cell delivery may account for some of the differences 
Table 2. Summary of Immunological Effects of Human SCs of Various Origin

\begin{tabular}{|c|c|c|c|c|c|}
\hline \multirow[b]{2}{*}{ SC Types/IEC } & \multicolumn{3}{|c|}{ Immune modulatory effect } & \multirow{2}{*}{$\frac{\text { Molecular mechanism }}{T}$} & \multirow{2}{*}{$\frac{\text { Immunogenicity }}{N K}$} \\
\hline & $T$ & $N K$ & $B$ & & \\
\hline BM-MSC & + & + & $\simeq$ & IDO & $* * *$ \\
\hline pBM-MSC & ++ & + & ++ & IDO & * \\
\hline OE-MSC & ++ & +++ & - & // & $* * *$ \\
\hline pOE-MSC & ++ & +++ & +++ & IDO & * \\
\hline LeSC & +++ & $\simeq$ & - & IDO/COX-2 & $* * *$ \\
\hline pLeSC & +++ & +++ & +++ & IDO & * \\
\hline AFS & + & $\simeq$ & $\simeq$ & $\mathrm{IDO} / \mathrm{IFN}-\gamma$ & $* * *$ \\
\hline pAFS & ++ & $\simeq$ & + & IDO $/$ IFN- $\gamma$ & * \\
\hline CSC & +++ & + & - & $\mathrm{IDO} / \mathrm{HO}-1$ & $* * *$ \\
\hline pCSC & +++ & + & ++ & IDO & ** \\
\hline LSC & +++ & + & - & IDO & $* * *$ \\
\hline pLSC & +++ & + & +++ & IDO & $* *$ \\
\hline
\end{tabular}

Inhibition range (\%)

Symbol

supportive effect

$0-20$

$20-50$

$50-75$

$>75$

$-$

$+$

$+++$

\begin{tabular}{lc} 
Susceptibility to NK-mediated lysis (\%) & Symbol \\
\hline $0-30$ & $*$ \\
$30-50$ & $* *$ \\
$>50$ & $* * *$
\end{tabular}

Results derived from immunomodulatory and immunogenicity assays are summarized to compare different SC type behavior; p: inflammatory primed. For immunogenicity assay, NK:SC ratio is $25: 1$
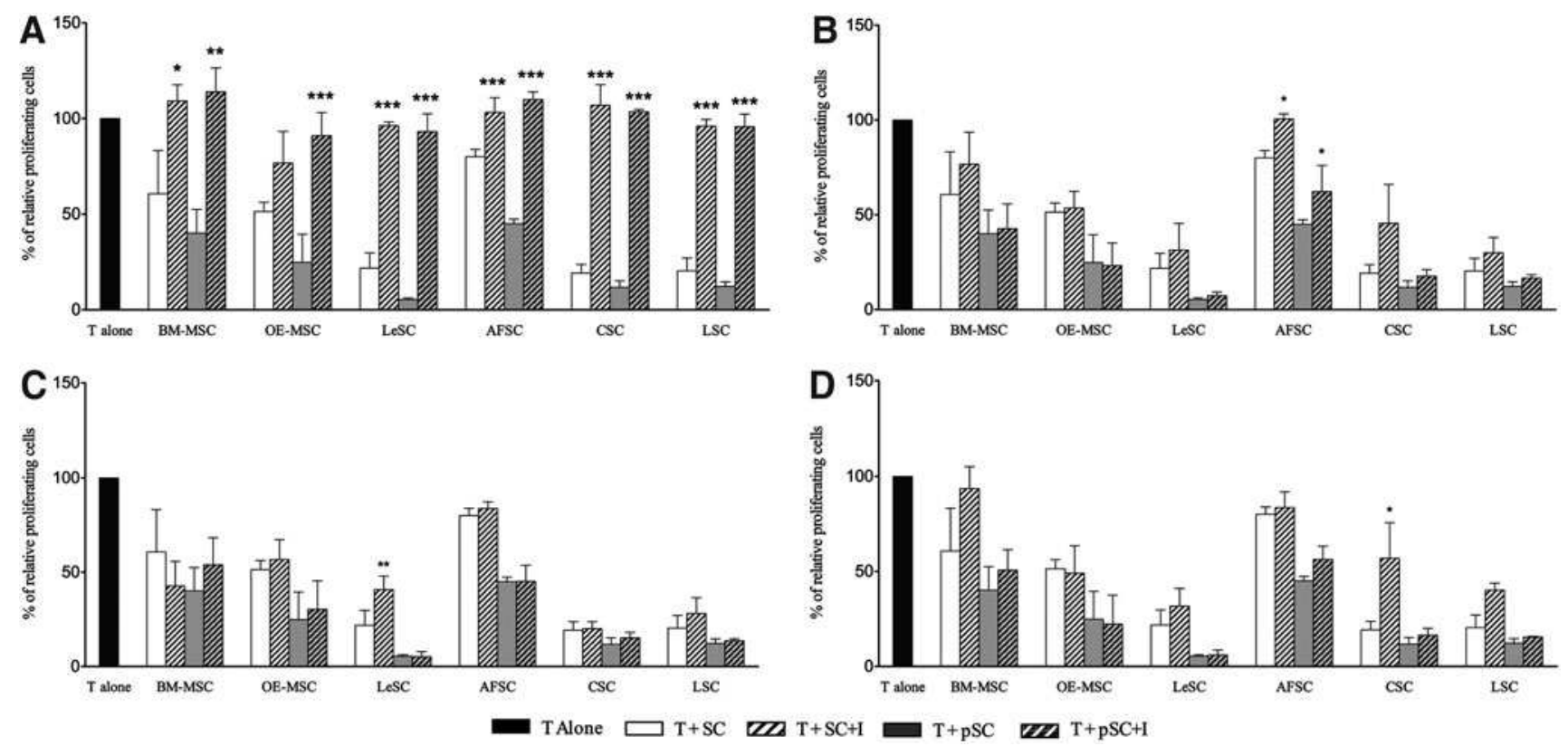

FIG. 4. Effect of specific inhibitors on T cell proliferation. Human purified T cells were stained with CFSE, stimulated with mitogenic anti-CD3 and anti-CD28 antibodies, and cultured alone or in presence of different resting and primed SC types (at 10:1 T/SCs ratio). In each coculture the following inhibitors (I) were added: L-1MT (A), Anti-IFN- $\gamma$ (B), NS-398 (C), and snPP (D). After 6 days, cells were harvested and T cell proliferation was evaluated by FACS analysis. The results are expressed as relative proliferation percentage of T cells, normalized to T cells cultured alone $(100 \%)$. Error bars represented mean $\pm S D$ of five independent experiments for BM-MSCs, OE-MSCs, LeSCs, and AFSCs and three independent experiments for CSCs and LSCs. ${ }^{*} P<0.05,{ }^{* *} P<0.01,{ }^{* * *} P<0.001$. 

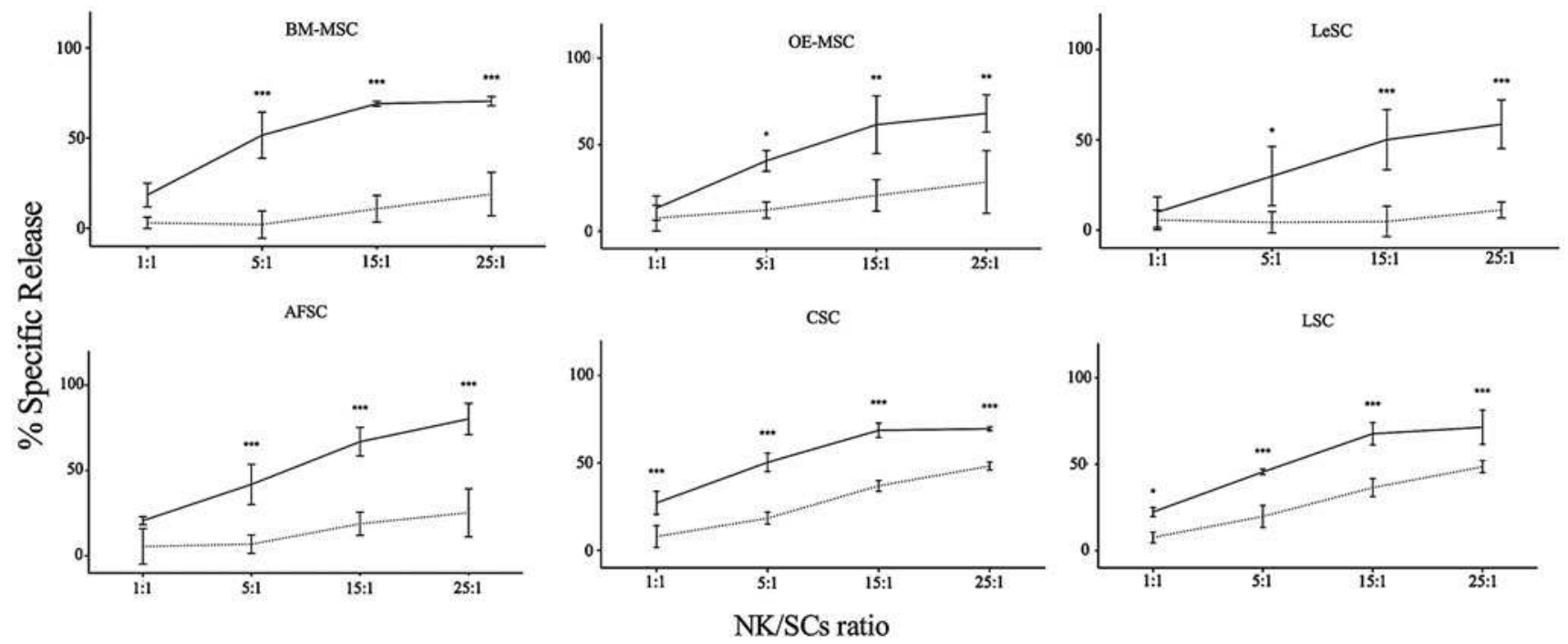

FIG. 5. Immunogenicity of resting and primed human SCs. To evaluate NK cytotoxicity, SCs were labeled with BATDA (as reported in Materials and Methods section) and then used as effector cells in coculture with IL-2-stimulated NK cells at different NK/SC ratios. The amount of cytotoxicity was calculated as release of fluorescence by lysed SCs, and detected by time-resolved fluorimeter (Victor X4 Multilabel Plate Reader, PerkinElmer). Each graphic shows the results obtained from five independent experiments, in which resting (solid line) and primed (dashed line) SCs were used as target cells. Data are expressed as percentage of fluorescence release. Error bars represented mean \pm SD of five independent experiments for BMMSCs, OE-MSCs, LeSCs, and AFSCs and three independent experiments for CSCs and LSCs. ${ }^{*} P<0.05,{ }^{* *} P<0.01,{ }^{* * *} P<0.001$. BATDA, bis-acetoxymethyl terpyridine dicarboxylate.

reported in the literature [12]. However, the immune modulatory function of BM-MSCs has been documented in graftversus-host disease [4-6], autoimmune encephalomyelitis [17], sepsis [3], collagen-induced arthritis, and bowel inflammation $[15,16,20]$. But whether other SC categories have the ability to exert comparable effects was unknown and our results provide novel information supporting the view that a variety of SCs share the critical aspect of being immune privileged.
An important distinction has to be emphasized among the SC types analyzed here. It is generally considered that the regenerative potential of transplanted SCs may be exerted either directly, through the engraftment of SCs inside the damaged tissue followed by proliferation and differentiation into novel terminally differentiated cell progeny, or indirectly, through the release of soluble factors favoring the healing processes mediated by resident SCs and contrasting the negative effect of inflammatory phenomena. The
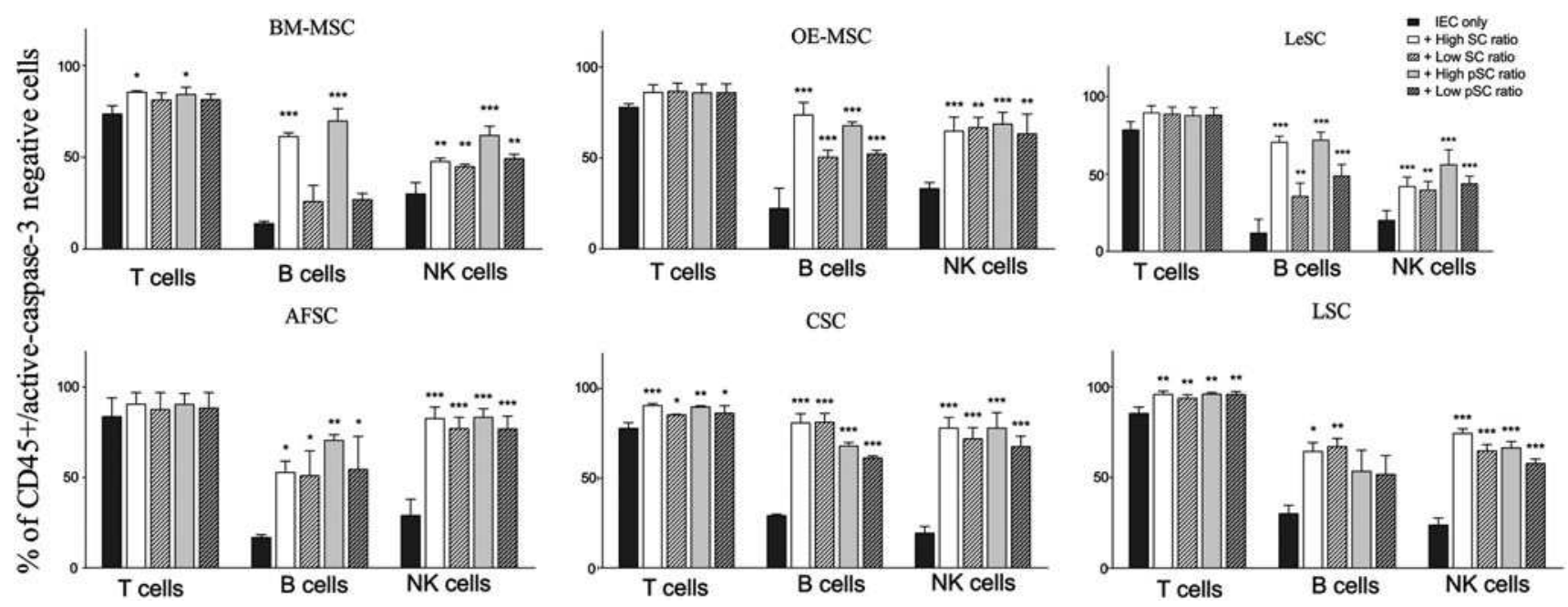

FIG. 6. Trophic support of resting and primed human SCs on different immune effectors. Resting and primed SCs were cocultured with unstimulated human IECs (ie, T, B, and NK cells). At the end of coculture, immune cell survival was detected by measuring cytosolic active-caspase-3 (as reported in Materials and Methods section). The results are expressed as percentage of caspase- $3^{\text {neg }} C D 45^{\text {pos }}$ cells, and the analysis was performed by flow cytometry. Error bars represented mean $\pm S D$ of five independent experiments for BM-MSCs, OE-MSCs, LeSCs, and AFSCs and three independent experiments for CSCs and LSCs. ${ }^{*} P<0.05,{ }^{* *} P<0.01,{ }^{* * *} P<0.001$. 
predominant therapeutic efficacy of MSCs and MSC-like SCs is mediated via a paracrine mechanism associated with the release of several cytokines that profoundly influence the response of IECs $[22,31,34,36-38,40,43]$. This principle applies to all SCs that modulate inflammation and have a limited capacity to generate a specialized progeny. However, they indirectly activate resident SCs, enhancing the repair of the organ [70-72]. Because of these characteristics, therapeutically, MSCs and MSC-like SCs may have to be repeatedly employed to exert their role long-term, in absence of clear evidence of their homing and persistence inside the tissues [14-20]. Conversely, the delivery of tissue-specific multipotent adult SCs, such as CSCs and LSCs, to the corresponding damaged organ fails to stimulate the resident SCs nested in proximity to or distant from the injured parenchyma [73,74]. Their exclusive beneficial effect is linked to their engraftment, expansion, and ultimately the regeneration of functionally-competent cells and vessels [50,53]. Thus, two important aspects have to be discussed. First, the recognition obtained in the current study in vitro that CSCs and LSCs interfere with the inflammatory microenvironment is strongly consistent with their inherent ability to home to and divide within the damaged tissue, which has been previously demonstrated experimentally $[53,73,74]$, in absence of inflammation in the parenchyma surrounding the integrated SCs shortly after their administration, or chronically in the regions adjacent to the regenerated myocardium, or lung structures. In other words, our data suggest that the immune modulatory properties of CSCs and LSCs here described in vitro for the first time may have a role in vivo in favoring their regenerative potential. Secondly, both CSCs and LSCs become structurally and functionally coupled with the cells of the recipient organ, creating new niches in which the SCs can divide asymmetrically $[73,75,76]$, thus ensuring the preservation of the SC pool and the formation of parenchymal and vascular cells $[50,53,77]$. It is likely that the potential clinical implementation of these SC populations is significantly strengthened by their immunomodulatory function. In vivo studies with each SC type are mandatory to assess the role of these immunological features in SC engraftment and regenerative potential. Similarly, further in vivo studies in animal models will clarify whether these considerations on CSCs and LSCs may be applied also to other c-Kit-positive SC populations, such as AFSCs [49], or to non-MSC SCs with in vitro and in vivo neurogenic potential, such as OE-MSCs [44-46] and LeSCs $[47,48]$.

As far as the general features related to the acquisition of the immune regulatory functions are concerned, the immunophenotype of the different SCs revealed a common switch, in response to inflammatory priming, from a resting to an activated immunosuppressive pattern. This change included the upregulation of MHC class I, the adhesion molecules ICAM-1 and VCAM-1, and the immunosuppressive molecule PD-L1 (CD274). Importantly, ICAM-1, VCAM1 , and PD-L1 strongly bind to IECs promoting cell-to-cell contact and exposing immune cells to immunosuppressive molecules [61-63]. A de novo expression of MHC class II was detected and, although this adaptation may theoretically favor an immune cell response, lymphocyte activation was never detected when cocultured with the variety of SC types investigated here. This result may reflect the absent or weak expression of the co-stimulatory molecules CD80 and CD86.
Our observations indicate that resting and primed SCs enhance the viability of unstimulated IECs rather than inhibiting their function. All SC types show an anti-apoptotic effect on T, B, and NK cells, suggesting that their potential inhibitory role $[12,22]$ is not a constitutive property of SCs, but is acquired through IEC activation. If SCs are not inflammatory-primed and are challenged with activated NK cells, the resulting interaction is SC lysis. However, IFN- $\gamma$ and TNF- $\alpha$ licensing makes SCs resistant to NK cells, a characteristic particularly apparent for B cell proliferation. A similar requirement has previously been shown for MSCs [27].

Here, we found that the exposure to inflammatory milieu leads to IDO activation that becomes the central immunosuppressive enzyme affecting $\mathrm{T}$ cell proliferation in all SC types, as shown previously also by other authors [36,38], even if some other molecules may be involved. The discrepancies among different published data could be related to different experimental approaches; thus, method and assay standardization is required to obtain comparable results, as suggested by ISCT MSC Committee [78].

In summary, our findings have provided new information concerning the immune modulatory properties of several SC types, an attribute that was previously unknown. It is now clear that immunomodulation is not a peculiar feature of MSC-like cells, but actually a general property of SCs that may be induced or enhanced by inflammatory stimuli. SC niches may be viewed as immunological structures playing a fundamental role in tissue homeostasis, by regulating the interplay of SCs and IECs, which promotes cell survival. With persistent antigen activation and immune responses, the immunological SC niche may become an important variable of the pathogenesis and progression of degenerative diseases. Understanding these mechanisms may help identifying novel therapeutic strategies or recognizing the most effective SC class able to interfere with damage-mediated inflammation, and to induce tissue regeneration and organ repair.

\section{Acknowledgments}

This work was supported by grants from CARIVERONA, Bando 2008 e 2012; Italian Ministry of University and Scientific Research-PRIN 2009; Ricerca Sanitaria Finalizzata 2008; Gruppo Animazione Lesionati Midollari (GALM) Verona; Federazione Associazioni Italiane Paratetraplegici (FAIP); 7th Framework Program of the European Commission: CASCADE (FP7-HEALTH-233236), and REBORNE (FP7-HEALTH-241879). The funders had no role in study design, data collection and analysis, decision to publish, or preparation of the article.

\section{Author Disclosure Statement}

No competing financial interests exist.

\section{References}

1. Constantin G, S Marconi, B Rossi, S Angiari, L Calderan, E Anghileri, B Gini, SD Bach, M Martinello, et al. (2009). Adipose-derived mesenchymal stem cells ameliorate chronic experimental autoimmune encephalomyelitis. Stem Cells 27:2624-2635. 
2. DelaRosa O and E Lombardo. (2010). Modulation of adult mesenchymal stem cells activity by toll-like receptors: implications on therapeutic potential. Mediators Inflamm 2010:865601.

3. Gonzalez-Rey E, P Anderson, MA Gonzalez, L Rico, D Buscher and M Delgado. (2009). Human adult stem cells derived from adipose tissue protect against experimental colitis and sepsis. Gut 58:929-939.

4. Le Blanc K, F Frassoni, L Ball, F Locatelli, H Roelofs, I Lewis, E Lanino, B Sundberg, ME Bernardo, M Remberger, G Dini, RM Egeler, A Bacigalupo, W Fibbe, O Ringden; Developmental Committee of the European Group for Blood and Marrow Transplantation. (2008). Mesenchymal stem cells for treatment of steroid-resistant, severe, acute graft-versus-host disease: a phase II study. Lancet 371:15791586.

5. Le Blanc K, I Rasmusson, B Sundberg, C Gotherstrom, M Hassan, M Uzunel and O Ringden. (2004). Treatment of severe acute graft-versus-host disease with third party haploidentical mesenchymal stem cells. Lancet 363:14391441.

6. Polchert D, J Sobinsky, G Douglas, M Kidd, A Moadsiri, E Reina, K Genrich, S Mehrotra, S Setty, B Smith and A Bartholomew. (2008). IFN-gamma activation of mesenchymal stem cells for treatment and prevention of graft versus host disease. Eur J Immunol 38:1745-1755.

7. Yañez R, ML Lamana, J García-Castro, I Colmenero, M Ramírez and JA Bueren. (2006). Adipose tissue-derived mesenchymal stem cells have in vivo immunosuppressive properties applicable for the control of the graft-versus-host disease. Stem Cells 24:2582-2591.

8. Zappia E, S Casazza, E Pedemonte, F Benvenuto, I Bonanni, E Gerdoni, D Giunti, A Ceravolo, F Cazzanti, et al. (2005). Mesenchymal stem cells ameliorate experimental autoimmune encephalomyelitis inducing T-cell anergy. Blood 106:1755-1761.

9. Okita K, N Nagata and S Yamanaka. (2011). Immunogenicity of induced pluripotent stem cells. Circ Res 109:720-721.

10. Pluchino S, L Zanotti, B Rossi, E Brambilla, L Ottoboni, G Salani, M Martinello, A Cattalini, A Bergami, et al. (2005). Neurosphere-derived multipotent precursors promote neuroprotection by an immunomodulatory mechanism. Nature 436:266-271.

11. Pittenger MF, AM Mackay, SC Beck, RK Jaiswal, R Douglas, JD Mosca, MA Moorman, DW Simonetti, S Craig and DR Marshak. (1999). Multilineage potential of adult human mesenchymal stem cells. Science 284:143-147.

12. Krampera M. (2011). Mesenchymal stromal cell 'licensing': a multistep process. Leukemia 25:1408-1414.

13. Krampera M, A Pasini, G Pizzolo, L Cosmi, S Romagnani and F Annunziato. (2006). Regenerative and immunomodulatory potential of mesenchymal stem cells. Curr Opin Pharmacol 6:435-441.

14. Uccelli A, L Moretta and V Pistoia. (2008). Mesenchymal stem cells in health and disease. Nat Rev Immunol 8: 726-736.

15. Fiorina P, M Jurewicz, A Augello, A Vergani, S Dada, S La Rosa, M Selig, J Godwin, K Law, et al. (2009). Immunomodulatory function of bone marrow-derived mesenchymal stem cells in experimental autoimmune type 1 diabetes. J Immunol 183:993-1004.

16. Gonzalez MA, E Gonzalez-Rey, L Rico, D Buscher and M Delgado. (2009). Treatment of experimental arthritis by in- ducing immune tolerance with human adipose-derived mesenchymal stem cells. Arthritis Rheum 60:1006-1019.

17. Rafei M, E Birman, K Forner and J Galipeau. (2009). Allogeneic mesenchymal stem cells for treatment of experimental autoimmune encephalomyelitis. Mol Ther 17:1799-1803.

18. Sun L, K Akiyama, H Zhang, T Yamaza, Y Hou, S Zhao, T Xu, A Le and S Shi. (2009). Mesenchymal stem cell transplantation reverses multiorgan dysfunction in systemic lupus erythematosus mice and humans. Stem Cells 27:1421-1432.

19. Uccelli A, G Mancardi and S Chiesa. (2008). Is there a role for mesenchymal stem cells in autoimmune diseases? Autoimmunity 41:592-595.

20. Zhang Q, S Shi, Y Liu, J Uyanne, Y Shi and AD Le. (2009). Mesenchymal stem cells derived from human gingiva are capable of immunomodulatory functions and ameliorate inflammation-related tissue destruction in experimental colitis. J Immunol 183:7787-7798.

21. Di Nicola M, C Carlo-Stella, M Magni, M Milanesi, PD Longoni, P Matteucci, S Grisanti and AM Gianni. (2002). Human bone marrow stromal cells suppress T-lymphocyte proliferation induced by cellular or nonspecific mitogenic stimuli. Blood 99:3838-3843.

22. Krampera M, L Cosmi, R Angeli, A Pasini, F Liotta, A Andreini, V Santarlasci, B Mazzinghi, G Pizzolo, et al. (2006). Role for interferon-gamma in the immunomodulatory activity of human bone marrow mesenchymal stem cells. Stem Cells 24:386-398.

23. Krampera M, S Glennie, J Dyson, D Scott, R Laylor, E Simpson and F Dazzi. (2003). Bone marrow mesenchymal stem cells inhibit the response of naive and memory antigenspecific T cells to their cognate peptide. Blood 101:37223729.

24. Le Blanc K, L Tammik, B Sundberg, SE Haynesworth and O Ringden. (2003). Mesenchymal stem cells inhibit and stimulate mixed lymphocyte cultures and mitogenic responses independently of the major histocompatibility complex. Scand J Immunol 57:11-20.

25. Menard C, L Pacelli, G Bassi, J Dulong, F Bifari, I Bezier, J Zanoncello, M Ricciardi, M Latour, et al. (2013). Clinicalgrade mesenchymal stromal cells produced under various GMP processes differ in their immunomodulatory properties: standardization of immune quality controls. Stem Cells Dev 22:1789-1801.

26. Prigione I, F Benvenuto, P Bocca, L Battistini, A Uccelli and V Pistoia. (2009). Reciprocal interactions between human mesenchymal stem cells and gammadelta $\mathrm{T}$ cells or invariant natural killer T cells. Stem Cells 27:693-702.

27. Spaggiari GM, A Capobianco, S Becchetti, MC Mingari and L Moretta. (2006). Mesenchymal stem cell-natural killer cell interactions: evidence that activated NK cells are capable of killing MSCs, whereas MSCs can inhibit IL-2-induced NKcell proliferation. Blood 107:1484-1490.

28. Krampera M, S Sartoris, F Liotta, A Pasini, R Angeli, L Cosmi, A Andreini, F Mosna, B Bonetti, et al. (2007). Immune regulation by mesenchymal stem cells derived from adult spleen and thymus. Stem Cells Dev 16:797-810.

29. Moorefield EC, EE McKee, L Solchaga, G Orlando, JJ Yoo, S Walker, ME Furth and CE Bishop. (2011). Cloned, CD117 selected human amniotic fluid stem cells are capable of modulating the immune response. PLoS One 6:e26535.

30. Najar M, G Raicevic, HI Boufker, H Fayyad-Kazan, C De Bruyn, N Meuleman, D Bron, M Toungouz and L Lagneaux. (2010). Adipose-tissue-derived and Wharton's jelly-derived mesenchymal stromal cells suppress lymphocyte responses 
by secreting leukemia inhibitory factor. Tissue Eng Part A 16:3537-3546.

31. Ren G, L Zhang, X Zhao, G Xu, Y Zhang, AI Roberts, RC Zhao and Y Shi. (2008). Mesenchymal stem cell-mediated immunosuppression occurs via concerted action of chemokines and nitric oxide. Cell Stem Cell 2:141-150.

32. Bouffi C, C Bony, G Courties, C Jorgensen and D Noel. (2010). IL-6-dependent PGE2 secretion by mesenchymal stem cells inhibits local inflammation in experimental arthritis. PLoS One 5:e14247.

33. Djouad F, LM Charbonnier, C Bouffi, P Louis-Plence, C Bony, F Apparailly, C Cantos, C Jorgensen and D Noel. (2007). Mesenchymal stem cells inhibit the differentiation of dendritic cells through an interleukin-6-dependent mechanism. Stem Cells 25:2025-2032.

34. Lukacs-Kornek V, D Malhotra, AL Fletcher, SE Acton, KG Elpek, P Tayalia, AR Collier and SJ Turley. (2011). Regulated release of nitric oxide by nonhematopoietic stroma controls expansion of the activated $\mathrm{T}$ cell pool in lymph nodes. Nat Immunol 12:1096-1104.

35. Matysiak M, W Orlowski, M Fortak-Michalska, A Jurewicz and K Selmaj. (2011). Immunoregulatory function of bone marrow mesenchymal stem cells in EAE depends on their differentiation state and secretion of PGE2. J Neuroimmunol 233:106-111.

36. Meisel R, A Zibert, M Laryea, U Gobel, W Daubener and D Dilloo. (2004). Human bone marrow stromal cells inhibit allogeneic T-cell responses by indoleamine 2,3-dioxygenasemediated tryptophan degradation. Blood 103:4619-4621.

37. Mellor AL and DH Munn. (2004). IDO expression by dendritic cells: tolerance and tryptophan catabolism. Nat Rev Immunol 4:762-774.

38. Mougiakakos D, R Jitschin, CC Johansson, R Okita, R Kiessling and K Le Blanc. (2011). The impact of inflammatory licensing on heme oxygenase-1-mediated induction of regulatory $\mathrm{T}$ cells by human mesenchymal stem cells. Blood 117:4826-4835.

39. Nemeth K, A Leelahavanichkul, PS Yuen, B Mayer, A Parmelee, K Doi, PG Robey, K Leelahavanichkul, BH Koller, et al. (2009). Bone marrow stromal cells attenuate sepsis via prostaglandin $\mathrm{E}(2)$-dependent reprogramming of host macrophages to increase their interleukin-10 production. Nat Med 15:42-49.

40. Ren G, J Su, L Zhang, X Zhao, W Ling, A L'Huillie, J Zhang, Y Lu, AI Roberts, et al. (2009). Species variation in the mechanisms of mesenchymal stem cell-mediated immunosuppression. Stem Cells 27:1954-1962.

41. Sato K, K Ozaki, I Oh, A Meguro, K Hatanaka, T Nagai, K Muroi and K Ozawa. (2007). Nitric oxide plays a critical role in suppression of T-cell proliferation by mesenchymal stem cells. Blood 109:228-234.

42. Selmani Z, A Naji, I Zidi, B Favier, E Gaiffe, L Obert, C Borg, P Saas, P Tiberghien, et al. (2008). Human leukocyte antigenG5 secretion by human mesenchymal stem cells is required to suppress $\mathrm{T}$ lymphocyte and natural killer function and to induce $\mathrm{CD} 4+\mathrm{CD} 25$ highFOXP3 + regulatory $\mathrm{T}$ cells. Stem Cells 26:212-222.

43. Spaggiari GM, A Capobianco, H Abdelrazik, F Becchetti, MC Mingari and L Moretta. (2008). Mesenchymal stem cells inhibit natural killer-cell proliferation, cytotoxicity, and cytokine production: role of indoleamine 2,3-dioxygenase and prostaglandin E2. Blood 111:1327-1333.

44. Delorme B, E Nivet, J Gaillard, T Häupl, J Ringe, A Devèze, J Magnan, J Sohier, M Khrestchatisky, et al. (2010). The hu- man nose harbors a niche of olfactory ectomesenchymal stem cells displaying neurogenic and osteogenic properties. Stem Cells Dev 19:853-866.

45. Girard SD, A Deveze, E Nivet, B Gepner, FS Roman and F Feron. (2011). Isolating nasal olfactory stem cells from rodents or humans. J Vis Exp pii:2762.

46. Nivet E, M Vignes, SD Girard, C Pierrisnard, N Baril, A Devèze, J Magnan, F Lanté, M Khrestchatisky, F Féron and FS Roman. (2011). Engraftment of human nasal olfactory stem cells restores neuroplasticity in mice with hippocampal lesions. J Clin Invest 121:2808-2820.

47. Bifari F, I Decimo, C Chiamulera, E Bersan, G Malpeli, J Johansson, V Lisi, B Bonetti, G Fumagalli, G Pizzolo and M Krampera. (2009). Novel stem/progenitor cells with neuronal differentiation potential reside in the leptomeningeal niche. J Cell Mol Med 13:3195-3208.

48. Decimo I, F Bifari, FJ Rodriguez, G Malpeli, S Dolci, V Lavarini, S Pretto, S Vasquez, M Sciancalepore, et al. (2011). Nestin- and doublecortin-positive cells reside in adult spinal cord meninges and participate in injury-induced parenchymal reaction. Stem Cells 29:2062-2076.

49. De Coppi P, G Bartsch, Jr., MM Siddiqui, T Xu, CC Santos, L Perin, G Mostoslavsky, AC Serre, EY Snyder, et al. (2007). Isolation of amniotic stem cell lines with potential for therapy. Nat Biotechnol 25:100-106.

50. Bearzi C, M Rota, T Hosoda, J Tillmanns, A Nascimbene, A De Angelis, S Yasuzawa-Amano, I Trofimova, RW Siggins, et al. (2007). Human cardiac stem cells. Proc Natl Acad Sci U S A 104:14068-14073.

51. Bolli R, AR Chugh, D D'Amario, JH Loughran, MF Stoddard, S Ikram, GM Beache, SG Wagner, A Leri, et al. (2011). Cardiac stem cells in patients with ischaemic cardiomyopathy (SCIPIO): initial results of a randomised phase 1 trial. Lancet 378:1847-1857.

52. Chugh AR, GM Beache, JH Loughran, N Mewton, JB Elmore, J Kajstura, P Pappas, A Tatooles, MF Stoddard, et al. (2012). Administration of cardiac stem cells in patients with ischemic cardiomyopathy: the SCIPIO trial: surgical aspects and interim analysis of myocardial function and viability by magnetic resonance. Circulation 126:S54-S64.

53. Kajstura J, M Rota, SR Hall, T Hosoda, D D'Amario, F Sanada, H Zheng, B Ogorek, C Rondon-Clavo, et al. (2011). Evidence for human lung stem cells. N Engl J Med 364: 1795-1806.

54. Rota C, B Imberti, M Pozzobon, M Piccoli, P De Coppi, A Atala, E Gagliardini, C Xinaris, V Benedetti, et al. (2012). Human amniotic fluid stem cell preconditioning improves their regenerative potential. Stem Cells Dev 21:1911-1923.

55. Dominici M, K Le Blanc, I Mueller, I Slaper-Cortenbach, F Marini, D Krause, R Deans, A Keating, D Prockop and E Horwitz. (2006). Minimal criteria for defining multipotent mesenchymal stromal cells. The International Society for Cellular Therapy position statement. Cytotherapy 8:315-317.

56. Liu Y, L Wang, T Kikuiri, K Akiyama, C Chen, X Xu, R Yang, W Chen, S Wang and S Shi. (2011). Mesenchymal stem cell-based tissue regeneration is governed by recipient $\mathrm{T}$ lymphocytes via IFN-gamma and TNF-alpha. Nat Med 17:1594-1601.

57. de Hoon MJ, S Imoto, J Nolan and S Miyano. (2004). Open source clustering software. Bioinformatics 20:1453-1454.

58. Saldanha AJ. (2004). Java Treeview-extensible visualization of microarray data. Bioinformatics 20:3246-3248.

59. Brooke G, H Tong, JP Levesque and K Atkinson. (2008). Molecular trafficking mechanisms of multipotent mesen- 
chymal stem cells derived from human bone marrow and placenta. Stem Cells Dev 17:929-940.

60. De Ugarte DA, Z Alfonso, PA Zuk, A Elbarbary, M Zhu, P Ashjian, P Benhaim, MH Hedrick and JK Fraser. (2003). Differential expression of stem cell mobilization-associated molecules on multi-lineage cells from adipose tissue and bone marrow. Immunol Lett 89:267-270.

61. Ren G, X Zhao, L Zhang, J Zhang, A L'Huillier, W Ling, AI Roberts, AD Le, S Shi, C Shao and Y Shi. (2010). Inflammatory cytokine-induced intercellular adhesion molecule- 1 and vascular cell adhesion molecule- 1 in mesenchymal stem cells are critical for immunosuppression. J Immunol 184:2321-2328.

62. Augello A, R Tasso, SM Negrini, A Amateis, F Indiveri, R Cancedda and G Pennesi. (2005). Bone marrow mesenchymal progenitor cells inhibit lymphocyte proliferation by activation of the programmed death 1 pathway. Eur J Immunol 35:1482-1490.

63. Luz-Crawford P, D Noel, X Fernandez, M Khoury, F Figueroa, F Carrion, C Jorgensen and F Djouad. (2012). Mesenchymal stem cells repress Th17 molecular program through the PD-1 pathway. PLoS One 7:e45272.

64. Najar M, G Raicevic, H Fayyad-Kazan, C De Bruyn, D Bron, $M$ Toungouz and L Lagneaux. (2012). Immune-related antigens, surface molecules and regulatory factors in human-derived mesenchymal stromal cells: the expression and impact of inflammatory priming. Stem Cell Rev 8:1188-1198.

65. Bottino C, R Castriconi, L Moretta and A Moretta. (2005). Cellular ligands of activating NK receptors. Trends Immunol 26:221-226.

66. Poggi A, C Prevosto, AM Massaro, S Negrini, S Urbani, I Pierri, R Saccardi, M Gobbi and MR Zocchi. (2005). Interaction between human NK cells and bone marrow stromal cells induces NK cell triggering: role of NKp30 and NKG2D receptors. J Immunol 175:6352-6360.

67. Benvenuto F, S Ferrari, E Gerdoni, F Gualandi, F Frassoni, V Pistoia, G Mancardi and A Uccelli. (2007). Human mesenchymal stem cells promote survival of $\mathrm{T}$ cells in a quiescent state. Stem Cells 25:1753-1760.

68. Caplan AI. (2007). Adult mesenchymal stem cells for tissue engineering versus regenerative medicine. J Cell Physiol 213:341-347.

69. Eming SA, T Krieg and JM Davidson. (2007). Inflammation in wound repair: molecular and cellular mechanisms. J Invest Dermatol 127:514-525.

70. Chen Y, LX Xiang, JZ Shao, RL Pan, YX Wang, XJ Dong and GR Zhang. (2010). Recruitment of endogenous bone marrow mesenchymal stem cells towards injured liver. J Cell Mol Med 14:1494-1508.
71. Sasaki M, R Abe, Y Fujita, S Ando, D Inokuma and H Shimizu. (2008). Mesenchymal stem cells are recruited into wounded skin and contribute to wound repair by transdifferentiation into multiple skin cell type. J Immunol 180:2581-2587.

72. Wu Y, L Chen, PG Scott and EE Tredget. (2007). Mesenchymal stem cells enhance wound healing through differentiation and angiogenesis. Stem Cells 25:2648-2659.

73. Anversa P, J Kajstura, M Rota and A Leri. (2013). Regenerating new heart with stem cells. J Clin Invest 123:62-70.

74. Anversa P, MA Perrella, S Kourembanas, AM Choi and J Loscalzo. (2012). Regenerative pulmonary medicine: potential and promise, pitfalls and challenges. Eur J Clin Invest 42:900-913.

75. Bearzi C, A Leri, F Lo Monaco, M Rota, A Gonzalez, T Hosoda, M Pepe, K Qanud, C Ojaimi, et al. (2009). Identification of a coronary vascular progenitor cell in the human heart. Proc Natl Acad Sci U S A 106:15885-15890.

76. Urbanek K, D Cesselli, M Rota, A Nascimbene, A De Angelis, T Hosoda, C Bearzi, A Boni, R Bolli, et al. (2006). Stem cell niches in the adult mouse heart. Proc Natl Acad Sci U S A 103:9226-9231.

77. Hosoda T, D D'Amario, MC Cabral-Da-Silva, H Zheng, ME Padin-Iruegas, B Ogorek, J Ferreira-Martins, S YasuzawaAmano, K Amano, et al. (2009). Clonality of mouse and human cardiomyogenesis in vivo. Proc Natl Acad Sci U S A 106:17169-17174.

78. Krampera M, J Galipeau, Y Shi, K Tarte, L Sensebe; and On behalf of the MSC Committee of the International Society for Cellular Therapy (ISCT). (2013). Immunological characterization of multipotent mesenchymal stromal cells-The International Society for Cellular Therapy (ISCT) working proposal. Cytotherapy pii: S1465-3249(13)00411-8.

$$
\begin{array}{r}
\text { Address correspondence to: } \\
\text { Dr. Mauro Krampera } \\
\text { Section of Hematology } \\
\text { Stem Cell Research Laboratory } \\
\text { Department of Medicine } \\
\text { University of Verona } \\
\text { Policlinico “G.B. Rossi," P.le L.A.Scuro, } 10 \\
37134 \text { Verona } \\
\text { Italy } \\
\\
\text { E-mail: mauro.krampera@univr.it } \\
\\
\text { Received for publication April 30, } 2013 \\
\text { Accepted after revision July 2, } 2013
\end{array}
$$

Prepublished on Liebert Instant Online XXXX XX, XXXX 